\title{
Lung Cell Oxidant Injury
}

\author{
ENHANCEMENT OF POLYMORPHONUCLEAR LEUKOCYTE-MEDIATED \\ CYTOTOXICITY IN LUNG CELLS EXPOSED TO SUSTAINED \\ IN VITRO HYPEROXIA
}

\author{
Norbert Suttorp and Lawrence M. Simon, Department of Medicine, Stanford \\ University School of Medicine, Veterans Administration Medical Center, \\ Palo Alto, California 94304
}

\begin{abstract}
A B S T R A C T The oxidant damage of lung tissue during in vivo hyperoxic exposure appears to be amplified by neutrophils that release toxic amounts of oxygen metabolites. In our studies cloned lung epithelial cells (L2 cells), lung fibroblasts, and pulmonary artery endothelial cells were cultured under either ambient $\left(\mathrm{PO}_{2}\right.$ $\sim 140$ torr $)$ or hyperoxic $\left(\mathrm{PO}_{2} \sim 630\right.$ torr $)$ conditions for $48 \mathrm{~h}$ ( $24 \mathrm{~h}$ for endothelial cells). After cultivation, phorbol myristate acetate- or opsonized zymosan-stimulated neutrophils were added to the cultivated monolayers for $4 \mathrm{~h}$, and lung cell damage was quantitated using ${ }^{51} \mathrm{Cr}$ release as an index. The data show that stimulated neutrophils are able to injure the three lung cell lines tested, with endothelial cells being highly susceptible to this injury and L2 cells being slightly more susceptible than lung fibroblasts. The studies also demonstrate that all three lung cell lines exposed to sustained hyperoxia are more susceptible to neutrophil-mediated cytotoxicity than their time-matched air controls. Hydrogen peroxide was the main toxic oxygen metabolite because catalase $(2,500 \mathrm{U} / \mathrm{ml}) \mathrm{com}$ pletely protected the target cells. Equivalent quantities of hydrogen peroxide generated by glucose oxidase instead of by neutrophils gave a similar degree of target cell injury. Superoxide dismutase at high concentrations $(250 \mu \mathrm{g} / \mathrm{ml})$ provided some protection. Other systems that detoxify oxygen metabolites were without protective effect. These findings indicate that the increase in susceptibility of lung cells to neutrophil-mediated oxidant damage is a toxic effect of hyperoxia
\end{abstract}

This work was presented in part at the meeting of the Western Society for Clinical Research in Carmel, CA, 1719 February 1982, and published in abstract form in 1982. Clin. Res. 30: 106a.

Received for publication 22 December 1981 and in revised form 13 April 1982. on lung cells. This specific manifestation of oxygen damage provides insight into the integration between primary mechanisms (oxygen exposure) and secondary mechanisms (release of oxygen metabolites by neutrophils) with respect to the cellular basis for pulmonary oxygen toxicity.

\section{INTRODUCTION}

Sustained in vivo exposure to abnormally high concentrations of oxygen results in extensive pathophysiologic alterations in the mammalian lungs. $(1,2)$ In vitro studies using isolated cells have demonstrated biochemical, structural, and functional alterations in alveolar epithelial cells $(3,4)$, lung fibroblasts (5), lung macrophages (6-9), and aorta endothelial cells (10) exposed to high partial pressure of oxygen.

Cell oxygen toxicity is generally attributed to the damaging effect of highly reactive metabolites of oxygen (e.g., superoxide anions, hydrogen peroxide, and hydroxyl radicals) (11-13). These metabolites are products of the incomplete biological reduction of $\mathrm{O}_{2}$ (14) and oxygen poisoning presumably is accounted for by an increase in their concentration $(15,16)$.

A second mechanism for in vivo oxygen toxicity may be a less specific "secondary" event, the release of toxic oxygen metabolites by polymorphonuclear leukocytes (PMN). ${ }^{1} \mathrm{~A}$ marked increase in the number of lung tissue PMN during hyperoxic exposure has been observed in multiple studies $(2,17,18)$ and after $60 \mathrm{~h}$ of oxygen exposure PMN are the second largest cell

\footnotetext{
${ }^{1}$ Abbreviations used in this paper: HBSS, Hanks' balanced salt solution; L2 cells, clone derived from type II pneumocyte; NBCS, newborn calf serum; PA-EC, pulmonary endothelial cell; PMA, phorbol myristate acetate; PMN, polymorphonuclear leukocyte; SOD, superoxidase dismutase.
} 
population in the lung interstitium (2). The influx of PMN in the lung coincides temporarily with death of the exposed animals (18). A study with oxygen-exposed neutropenic rabbits showed that neutropenia protected the animals in terms of less lung edema, better gas exchange, and longer survival (19). Studies using in vitro cell systems have, in fact, demonstrated a toxic effect of stimulated PMN related to release of reactive oxygen metabolites (20). Hydrogen peroxide $\left(\mathrm{H}_{2} \mathrm{O}_{2}\right)$, $(21,22)$ superoxide anions $\mathrm{O}_{\overline{2}}^{-}(23)$, and hydroxyl radicals $\left(\mathrm{OH}^{\circ}\right)(24)$ have all been implicated in PMN-mediated cell damage. A relationship between "primary" cell damage directly related to exposure of lung cells to high oxygen tensions, and "secondary" effects mediated by PMN-released toxic metabolites, would presumably result in "additive" lung cell damage during in vivo hyperoxia. The integration between these two mechanisms during prolonged oxygen exposure has not been examined, but is central to an understanding of the cellular basis for pulmonary oxygen toxicity.

In our studies we have therefore developed an in vitro system for examining the effect of sustained exposure to high oxygen tensions on susceptibility of different lung cell types to PMN-mediated cytotoxicity. The system has allowed us to: $(a)$ quantitate PMNinduced cytotoxicity in cells maintained under ambient and high oxygen tensions for 24-48 h, (b) compare the susceptibility of different lung cell lines to PMN cytotoxic mechanisms, and $(c)$ determine the relative importance of different oxygen metabolites as PMN effector mechanisms in lung cell damage.

The results suggest that: $(a)$ the direct toxicity of sustained hyperoxia markedly increases the susceptibility of lung cell systems to PMN-mediated oxidant damage; $(b)$ endothelial cells are (intrinsically) least resistant to oxidant damage; (c) $\mathrm{H}_{2} \mathrm{O}_{2}$ is a critical metabolite for PMN cytotoxicity in this mixed cell system.

\section{METHODS}

\section{Cell preparation}

Target cells. Lung epithelial cells, a clone derived from rat type II pneumocytes (25) and maintained as frozen cell suspensions were rapidly thawed and plated in T-75 tissue culture flasks (Corning Medical, Corning Glass Works, Medfield, MA) and maintained to confluence $(\sim 7 \mathrm{~d})$ at $37^{\circ} \mathrm{C}$ in 95\% air-5\% $\mathrm{CO}_{2}$, using Ham's F12 tissue culture medium ( $\mathrm{pH}=7.4$ ) supplemented with $10 \%$ newborn calf serum (F12-10\%, NBCS) from Gibco Laboratories, Grand Island Biological Co., Grand Island, NY. The F12-10\% NBCS and all culture media used contained penicillin $(100 \mathrm{U} / \mathrm{ml})$ and gentamicin $(25 \mu \mathrm{g} / \mathrm{ml})$. Confluent plates were dispersed in a collagenase-trypsin-chicken serum solution (26) and replated with a 1:4 split or subcultured to Leighton tubes at a density of $1 \times 10^{5}$ cells. At the time of confluence $(\sim 4 \mathrm{~d})$ the cells in Leighton tubes were incubated in F12-10\% NBCS containing $3 \mu \mathrm{Ci}$ of sodium chromate $\left(\mathrm{Na}_{2}{ }^{51} \mathrm{CrO}_{4}, 1 \mathrm{mCi}\right.$ / $\mathrm{ml}$, New England Nuclear, Boston, MA) overnight at $37^{\circ} \mathrm{C}$. The monolayers were then washed three times with F12, refed, and incubated in stoppered Leighton tubes under either hyperoxic or control (ambient) conditions for an additional $48 \mathrm{~h}$. Hyperoxia was achieved by gassing culture tubes with $95 \%$ oxygen-5\% $\mathrm{CO}_{2}$ for $1 \mathrm{~min}$ at a flow rate of 2 liter/min. Multiple measurements of media $\mathrm{Po}_{2}$ (Corning $165 \mathrm{pH}$, Blood Gas Analyzer, Corning Medical) indicated that the $\mathrm{PO}_{2}$ was maintained at $\sim 630$ torr throughout the 48-h cultivation period. Control (ambient) conditions were achieved by gassing with $95 \%$ air-5\% $\mathrm{CO}_{2}$ resulting in a media $\mathrm{Po}_{2} \sim 140$ torr.

Rat lung fibroblasts were obtained as described (27) and were similarly plated, subcultured, labeled, gassed, and incubated under hyperoxic and control conditions for $48 \mathrm{~h}$ in F12-10\% NBCS.

Calf pulmonary artery endothelial cells (PA-EC) were obtained from the American Tissue Culture Collection (Rockville, MD) as frozen cell suspensions, maintained to confluence in T-25 culture flasks (Corning Medical) using media 199 (Earle's base) (Gibco Laboratories) supplemented with $20 \%$ fetal bovine serum (Associated Biomedical Systems, Inc., Buffalo, NY). The PA-EC were then dispersed in a trypsin solution (28) and confluent monolayers were prepared and incubated (as above) for 24-48 $\mathrm{h}$ in stoppered Leighton tubes under control and hyperoxic conditions.

All monolayers were refed and regassed after $24 \mathrm{~h}$. At this time, and after $48 \mathrm{~h}$ the amount of ${ }^{51} \mathrm{Cr}$ in the media was counted in order to monitor spontaneous chromium release under different exposure conditions.

Effector cells. PMN were harvested from the peritoneal cavity of 25-30 g Swiss Webster mice (Simonson Laboratories, San Francisco, CA) $12 \mathrm{~h}$ after intraperitoneal injection of $3 \mathrm{ml}$ of $12 \%$ (wt/vol) casein suspension (Difco Laboratories, Detroit, MI) (29). Erythrocytes were subjected to hypotonic lysis and the cell suspension was then washed twice in Hanks' balanced salt solution (HBSS) (pH 7.4, $11 \mathrm{mM}$ glucose) (Gibco Laboratories). At least $85 \%$ of the cells used were PMN as determined by differential cell count. Cell viability was always $>95 \%$ as judged by trypan blue exclusion.

Cytotoxicity assay. Following the period of incubation under ambient or hyperoxic conditions varying number of PMN $\left(2.5 \times 10^{5}-1.6 \times 10^{7}\right)$ were added to the labeled target cells using an incubation solution of HBSS (pH 7.4, $11 \mathrm{mM}$ glucose), final volume $0.4 \mathrm{ml}$. This range of PMN provided an effector/target cell ration between $1: 1$ and 64:1. Experiments were initiated by adding phorbol myristate acetate (PMA, final concentration $0.25 \mu \mathrm{g} / \mathrm{ml}$ ) or opsonized zymosan (final concentration $3.1 \mathrm{mg} / \mathrm{ml}$ ). PMA (Sigma Chemical Co., St. Louis, MO) stock solutions $(1 \mathrm{mg} / \mathrm{ml})$ were stored in dimethylsulfoxide at $-80^{\circ} \mathrm{C}$. Opsonized zymosan was prepared freshly as required [ $50 \mathrm{mg}$ of zymosan A (Sigma Chemical Co.) was incubated in $4 \mathrm{ml}$ of pooled human AB serum (Gibco Laboratories) and $2 \mathrm{ml}$ of HBSS for 30 minutes at $37^{\circ} \mathrm{C}$, zymosan particles pelleted, and resuspended in $4 \mathrm{ml}$ of HBSS]. After initiating the reaction, sealed Leighton tubes were incubated in air at $37^{\circ} \mathrm{C}$ for $4 \mathrm{~h}$. In some experiments PMN were replaced by glucose oxidase (type V, 1,050 U/ ml, Sigma Chemical Co.).

Other additions to this cytotoxic system were bovine superoxide dismutase $(2,600 \mathrm{U} / \mathrm{mg}$ protein), bovine liver catalase $(37,000 \mathrm{U} / \mathrm{mg}$ protein), thymol free catalase $\mathrm{C}-40$ $(17,000 \mathrm{U} / \mathrm{mg}$ protein, no effect of thymol was noticed), sodium azide, mannitol, and thiourea (Sigma Chemical Co.) and albumin (Miles Laboratories, Inc., Elkhart, IN) (Table II). Dismutation of superoxide anions by the added super- 
oxide dismutase (SOD) and breakdown of $\mathrm{H}_{2} \mathrm{O}_{2}$ by added catalase throughout the incubation period was confirmed in separate studies.

After $4 \mathrm{~h}$ incubation, cytotoxicity was determined by quantitating ${ }^{51} \mathrm{Cr}$ release from target cells $(21,22)$. The incubation solution (HBSS) was transferred to a counting tube, centrifuged at $1,000 \mathrm{~g}$ for $10 \mathrm{~min}$, and half of the supernatant (containing only cell-free ${ }^{51} \mathrm{Cr}$ ) transferred to a second counting tube. Cells left in the Leighton tubes were removed with a rubber policeman and transferred to a third counting tube. Cytotoxicity was expressed as the percentage of ${ }^{51} \mathrm{Cr}$ released from target cells and calculated by the formula: percent cytotoxicity $=([A-B] / C) \times 100$ where $A$ is the counts per minute in the media (second counting tube $\times 2$ ) of systems containing stimulated PMN or glucose oxidase and target cells, B is counts per minute of spontaneously released ${ }^{51} \mathbf{C r}$ into the media of systems containing target cells and unstimulated PMN, $\mathrm{C}$ is the total initial counts per minute in the target cells. In Fig. 2, results are expressed as the percentage of ${ }^{51} \mathrm{Cr}$ released, with spontaneous release (expression B) separately shown.

Superoxide anion generation in PMN. $\mathrm{O}_{\overline{2}}^{-}$was determined by the superoxide dismutase inhibitable reduction of cytochrome c (30). $5 \times 10^{5} \mathrm{PMN}$ were incubated in $1.5 \mathrm{ml}$ of HBSS (pH 7.4, $11 \mathrm{mM}$ glucose), $60 \mu \mathrm{M}$ cytochrome c (type VI, Sigma Chemical Co.) and $0.25 \mu \mathrm{g} / \mathrm{ml}$ PMA. Control preparations also contained $40 \mathrm{U} / \mathrm{ml}$ superoxide dismutase. Experimental and control tubes were incubated at $37^{\circ} \mathrm{C}$ for $15 \mathrm{~min}$. Absorbance differences between the cell-free supernatant of experimental and control samples was determined on a Beckman model 25 spectrophotometer (Beckman Instruments, Inc., Fullerton, CA) at $550 \mathrm{~nm}$. $\mathrm{O}_{\mathbf{2}}^{-}$generation was calculated using an extinction coefficient of $19.1 \mathrm{mM}^{-1}$ $\mathrm{cm}^{-1}$ for reduced minus oxidized cytochrome $\mathrm{c}$ (31).

Hydrogen peroxide generation in $P M N$. $\mathrm{H}_{2} \mathrm{O}_{2}$ production was determined by the technique of Root and colleagues $(32,33) .5 \times 10^{5}$ PMN were incubated in HBSS ( $\mathrm{pH} 7.4$ ) containing $11 \mathrm{mM}$ glucose, $12 \mu \mathrm{M}$ scopoletin (Sigma Chemical Co.), $30 \mathrm{U}$ horse radish peroxidase grade 1 (Boehringer Mannheim Biochemicals, Indianapolis, IN, $10 \mathrm{mg} / \mathrm{ml}$ ) and $1 \mathrm{mM}$ azide for $15 \mathrm{~min}$ at $37^{\circ} \mathrm{C}$. PMA $(0.25 \mu \mathrm{g} / \mathrm{ml})$ was used to initiate the reaction. The spontaneous decay of scopoletin fluorescence in the absence of cells served as a control. Supernatants of experimental and control samples were excited at $350 \mathrm{~nm}$ and fluorescence emitted at $460 \mathrm{~nm}$ was measured using a Turner model 430 spectrofluorometer (SequoiaTurner, Mountain View, CA). The difference between $\mathrm{H}_{2} \mathrm{O}_{2}-$ induced and spontaneous decrease in fluorescence was used to calculate $\mathrm{H}_{2} \mathrm{O}_{2}$ generation.

Statistical methods. Data were analyzed by the twotailed Student's test for unpaired samples (34).

\section{RESULTS}

Preferential destruction of hyperoxically grown lung cells. As shown in Table I PMA-stimulated PMN are cytotoxic for $\mathrm{L} 2$ cells with hyperoxia substantially increasing susceptibility to this cytotoxicity. Neither PMA or PMN alone produce significant cell damage. Fig. 1 summarizes data on PMN-mediated cytotoxicity with increasing effector/target cell ratios in L2 cells cultivated under ambient or hyperoxic conditions. Similar data on two additional lung cell types (lung fibroblasts and pulmonary artery endothelial cells) are
TABLE I

Preferential Destruction of Hyperoxically Grown L2 Cell Monolayers By PMA-stimulated Neutrophils

\begin{tabular}{|c|c|c|}
\hline \multirow[b]{3}{*}{ Additives } & \multicolumn{2}{|c|}{$\begin{array}{l}\text { Percent cytotoxicity (experimental } \\
\text { - spontaneous }{ }^{51} \mathrm{Cr} \text { release) }\end{array}$} \\
\hline & \multicolumn{2}{|c|}{ L2 cell cultivation conditions } \\
\hline & Air $\times 48 \mathrm{~h}$ & Hyperoxia $\times 48 \mathrm{~h}$ \\
\hline Neutrophils $\ddagger$ & $1.4 \pm 0.9$ & $1.8 \pm 1.9$ \\
\hline PMA $\S$ & $-0.4 \pm 0.7$ & $0.3 \pm 0.7$ \\
\hline Neutrophils $\ddagger$ + PMA $\S$ & $14.6 \pm 3.0$ & $38.1 \pm 3.9^{\prime \prime}$ \\
\hline
\end{tabular}

- Results are expressed as mean $( \pm \mathrm{SE})$ cytotoxicity $(n=10)$ of confluent $\mathrm{L} 2$ cell monolayers $\left(2.5 \times 10^{5}\right.$ cells $)$. Target cells and additives were incubated in HBSS ( $\mathrm{pH} 7.4,11 \mathrm{mM}$ glucose) over $4 \mathrm{~h}$ at $37^{\circ} \mathrm{C}$ in air. The spontaneous ${ }^{51} \mathrm{Cr}$ release was $6.8 \pm 1.8 \%$ for aerobically grown L2 cells and $6.6 \pm 1.1 \%$ for the hyperoxically grown cells.

Neutrophil number was $8 \times 10^{6}$.

\$ Final phorbol myristate acetate concentration was $0.25 \mu \mathrm{g} / \mathrm{ml}$.

" $P<0.001$ as compared with the aerobically grown $\mathrm{L} 2$ cells.

shown. In all three lung cell lines tested there is a substantial increase in susceptibility to neutrophil-mediated damage in cells maintained under hyperoxic conditions for 24 (PA-EC) or 48 (L2 and lung fibroblasts) $h$ as compared with culture systems maintained under ambient conditions. For example, 0.5 million stimulated PMN produce $14.9 \%$ cytotoxicity in aero-



Figure 1 Toxic effect of varying number of neutrophils, stimulated with PMA $(0.25 \mu \mathrm{g} / \mathrm{ml})$, on confluent monolayers $\left(\sim 2.5 \times 10^{5}\right.$ cells $)$ of three lung cell lines over a 4-h incubation period in air. Lung fibroblasts were grown in air $\left(\mathrm{PO}_{2}\right.$ $\sim 140$ torr) $(\square)$ or in hyperoxia $\left(\mathrm{PO}_{2} \sim 630\right.$ torr) (ם) for 48 $\mathrm{h}, \mathrm{L2}$ cells for $48 \mathrm{~h}$ in air (O) or in hyperoxia (O), and pulmonary artery endothelial cells for $24 \mathrm{~h}$ in air $(\Delta)$ or hyperoxia $(\Delta)$. Spontaneous ${ }^{51} \mathrm{Cr}$ release was $5.6 \pm 3.2$ for $(\square)$, $6.0 \pm 4.1$ for $(\square), 7.2 \pm 2.1$ for $(0), 7.4 \pm 3.6$ for $(0), 8.7 \pm 2.0$ for $(\Delta)$, and $10.0 \pm 2.9$ for $(\Delta)$. Results are shown as mean $( \pm \mathrm{SE})$ cytotoxicity (experimental - spontaneous ${ }^{51} \mathrm{Cr}$ release) for 10 separate experiments. 
bically maintained PA-EC compared with $32.4 \%$ in hyperoxically grown PA-EC. Likewise, 4 million PMN produce threefold greater damage in oxygen-exposed L2 cells as compared with air-grown systems. Similar results are seen for lung fibroblasts.

The data for PA-EC were obtained after a 24-h exposure period because $48 \mathrm{~h}$ of hyperoxic exposure resulted in overt cell damage. (As indicated by a significantly greater spontaneous release of ${ }^{51} \mathrm{Cr}$ in oxygen grown PA-EC as compared with air-grown systemsair: $18.9 \pm 3.3 \% / 12 \mathrm{~h}$, hyperoxia: $32.7 \pm 1.8 \% / 12 \mathrm{~h}, P$ $<0.01)$. This difference in spontaneous release was not seen in L2 cells or LF after the $48 \mathrm{~h}$ of high oxygen exposure, reflecting a high susceptibility of endothelial cells to chronic hyperoxia.

PMA as a soluble membrane pertubant is a very powerful stimulus for initiating all aspects of respiratory burst $(35,36)$. As a more physiologic stimulus we used opsonized zymosan, which induces phagocytosis and triggers the burst, most likely via a specific receptor interaction $(37,38)$.

Opsonized zymosan proved to be a somewhat weaker stimulus for PMN but by using L2 cells as targets, similar results regarding susceptibility of hyperoxic systems were seen. There is moderate cytolysis in the aerobically grown monolayers and a significantly $(P$ $<0.001)$ higher cytotoxicity in hyperoxically maintained cells (Fig. 2).



Figure 2 Cytotoxic effect of PMN, stimulated with $3.1 \mathrm{mg} /$ ml opsonized zymosan (Op,Zy) on $\square=$ aerobically or $\mathbb{Z}$ $=$ hyperoxically cultivated L2 monolayers $\left(2.5 \times 10^{5}\right.$ cells $)$ at an effector/target cell ratio of $40: 1$ over a 4 -h period of incubation at $37^{\circ} \mathrm{C}$ in air. Also shown the effect of SOD (650 $\mathrm{U} / \mathrm{ml})$ and catalase $(2,500 \mathrm{U} / \mathrm{ml})$ under these conditions. NS $=$ not significant.
Differential susceptibility of lung cells to PMNmediated cell destruction. A further observation shown in Fig. 1 is the difference in susceptibility of the three cell lines tested to PMN-mediated cytotoxicity. The order of this differential susceptibility is PAEC $>$ L2 $>$ LF. Experiments regarding the comparison of the three lung cells were done simultaneously, i.e., the target cells were exposed to the same PMN preparation and to the same batch of PMA. While $12 \times 10^{6}$ stimulated PMN are required to produce $23.4 \%$ cytotoxicity in L2 cells and $9 \%$ cytotoxicity in LF, only $2 \times 10^{6}$ PMN result in $37.1 \%$ PA-EC cytolysis. This high susceptibility of endothelial cells to PMN-mediated cytotoxicity as compared with the other two lung cells is significant at every number of PMN tested $(P<0.001)$. The difference between L2 cells and LF is less pronounced but significant in the presence of 4 and 8 million neutrophils $(P<0.05)$.

Role of active oxygen species in PMN-mediated lung cell destruction. It has been shown that stimulated PMN destroy a variety of different targets by generating active oxygen species such as $\mathrm{O}_{\overline{\mathbf{2}}}(23,39)$, $\mathrm{H}_{2} \mathrm{O}_{2}(21,22)$, and $\mathrm{OH}^{\circ}(24)$. To define a possible role of these toxic oxygen species in the cytolysis of $\mathrm{L} 2$ cells, experiments were performed in the presence of systems that detoxify reactive oxygen metabolites. Pertinent data are illustrated in Fig. 2 and Table II.

In the presence of catalase, which degrades $\mathrm{H}_{2} \mathrm{O}_{2}$, highly significant protection is seen $(P<0.001)$ for all three target cells used, with ${ }^{51} \mathrm{Cr}$ release dropping to control levels. Heat inactivated catalase had no protective effect. Hydrogen peroxide, a halide, and myeloperoxidase can interact to form a powerful cytotoxic system (40) that usually is blocked by $0.1 \mathrm{mM}$ azide (41). In this study however, azide did not reduce cytotoxicity. SOD, which metabolizes $\mathrm{O}_{\overline{2}}^{\overline{2}}$, had no protective effect at a concentration of $260 \mathrm{U} / \mathrm{ml}(100 \mu \mathrm{g} /$ $\mathrm{ml})$. Higher concentrations of SOD $(650 \mathrm{U}=250 \mu \mathrm{g} /$ $\mathrm{ml})$ showed a significant $(P<0.05)$ reduction $(\sim 50 \%)$ in cytotoxicity. Heat-inactivated SOD was without effect. Because the $\mathrm{Cu}-\mathrm{Zn}$ SOD at high concentration has a peroxidative effect $(42,43)$ and because no studies with the Mn-containing SOD were done, a definitive involvement of superoxide anion in the cytotoxic event is not established.

Stimulated PMN can result in generation of the very powerful oxidant $\mathrm{OH}^{*}(44,45)$. However, the addition of mannitol or of thiourea, a more powerful scavenger of $\mathrm{OH}^{*}$ (46) did not decrease PMN-mediated cytotoxicity, despite the high concentrations used (Table II). All reagents added were tested for their effect on the respiratory burst. Mannitol $(50 \mathrm{mM})$ did produce a slight decrease in $\mathrm{O}_{\overline{2}}^{-}$and $\mathrm{H}_{2} \mathrm{O}_{2}$ generation. Because PMA is dissolved in dimethylsulfoxide and because dimethylsulfoxide is a hydroxyl radical quencher (46), 
TABLE II

Cytotoxic Effect of PMA- or Opsonzied Zymosan-stimulated Neutrophils On Confluent L2 Cell Monolayers

\begin{tabular}{|c|c|}
\hline Additions to L2 cells! & $\begin{array}{c}\text { Percent } \\
\text { cytotoxicity } \pm \text { SE } \\
\text { (experimental } \\
\text { - spontaneous s' } \mathrm{Br} \\
\text { release) }\end{array}$ \\
\hline Neutrophils + PMA§ " (26)ף & $32.1 \pm 2.3$ \\
\hline $\begin{array}{l}\text { Neutrophils + PMA + catalase }(2,500 \mathrm{U} / \mathrm{ml}) \\
(10)\end{array}$ & $0.2 \pm 2.1 \S \S$ \\
\hline $\begin{array}{l}\text { Neutrophils + PMA + catalase (autoclaved) } \\
\text { (4) }\end{array}$ & $33.9 \pm 4.4$ \\
\hline $\begin{array}{l}\text { Neutrophils + PMA + SOD }(650 \mathrm{U} / \mathrm{ml})^{\bullet \bullet} \\
\text { (15) }\end{array}$ & $15.3 \pm 3.2^{\|\|} \|$ \\
\hline Neutrophils + PMA + SOD $(260 \mathrm{U} / \mathrm{ml})(4)$ & $27.3 \pm 5.8$ \\
\hline Neutrophils + PMA + SOD (autoclaved) (4) & $31.1 \pm 8.4$ \\
\hline Neutrophils + PMA + thiourea $(15 \mathrm{mM})(11)$ & $35.0 \pm 3.3$ \\
\hline Neutrophils + PMA + mannitol $(50 \mathrm{mM})(8)$ & $21.2 \pm 5.0$ \\
\hline Neutrophils + PMA + azide (0.1 mM) (7) & $37.2 \pm 4.1$ \\
\hline Neutrophils + opsonized zymosan $\sharp$ (4) & $24.5 \pm 5.2$ \\
\hline $\begin{array}{l}\text { Neutrophils }+ \text { opsonized zymosan }+ \text { thiourea } \\
(15 \mathrm{mM})(4)\end{array}$ & $30.4 \pm 5.6$ \\
\hline
\end{tabular}

- Results are expressed as mean $( \pm \mathrm{SE})$ cytotoxicity of L2 cell monolayers $\left(2.5 \times 10^{5}\right.$ cells $)$.

\ Target cells and additives were incubated in HBSS (pH 7.4, 11 $\mathrm{mM}$ glucose) over $4 \mathrm{~h}$ at $37^{\circ} \mathrm{C}$. The spontaneous ${ }^{51} \mathrm{Cr}$ release ranged between $8.8 \pm 0.8 \%$ for L2 cells + PMA and $14.9 \pm 2.9 \%$ for L2 cells + PMA + azide

$\$$ Neutrophil number was $16 \times 10^{6}$.

"Final PMA concentration was $0.25 \mu \mathrm{g} / \mathrm{ml}$.

I Number of determinations.

$\because$ SOD = superoxide dismutase.

\# Final opsonized zymosan concentration $3.1 \mathrm{mg} / \mathrm{ml}$.

$\$ \$ P<0.001$ as compared with L2 cells + neutrophils + PMA.

"II $P<0.005$ as compared to L2 cells + neutrophils + PMA.

a potential effect of thiourea or mannitol could be obscured by $\mathrm{OH}^{*}$ quenching in all PMA studies, experiments were therefore carried out with opsonized zymosan as the stimulus for the PMN. Under these conditions thiourea similarly had no protective effect.

Quantitative aspects of hydrogen peroxide-mediated lung cell destruction. The data presented lend strong support to $\mathrm{H}_{2} \mathrm{O}_{2}$ as an essential mediator of PMN-induced lung cell destruction. To confirm these observations experiments were performed in which the stimulated neutrophils were replaced by glucose/glucose oxidase, a system that divalently reduces oxygen to $\mathrm{H}_{2} \mathrm{O}_{2}$. Table III illustrates that this $\mathrm{H}_{2} \mathrm{O}_{2}$ generating system does produce $\mathrm{L} 2$ cell damage, which is prevented by the addition of catalase. One million mouse neutrophils generate $49.7 \pm 7.8 \mathrm{nmol} \mathrm{O}_{\overline{2}}^{-}$and $4.5 \pm 0.5$ $\mathrm{nmol} \mathrm{H}_{2} \mathrm{O}_{2}(n=6, \mathrm{SE})$ in $15 \mathrm{~min}$ in the presence of $0.25 \mu \mathrm{g} / \mathrm{ml}$ PMA. The glucose oxidase system, generating no superoxide anion (47) and $7.2 \mathrm{nmol} \mathrm{H}_{2} \mathrm{O}_{2}$ /
TABLE III

Cytotoxic Effect of Glucose Oxidase on Confluent L2 Cell Monolayers

\begin{tabular}{|c|c|}
\hline Additions to $L 2$ cellst & $\begin{array}{l}\text { Percent Cytotoxicity } \pm S E \\
\text { (experimental - spontaneous } \\
\left.{ }^{81} \mathrm{Cr} \text { release }\right)\end{array}$ \\
\hline GO $6 \mathrm{mU}(6)^{\| \prime}$ & $17.1 \pm 5.8$ \\
\hline GO $8 \mathrm{mU}(8)$ & $38.2 \pm 4.5$ \\
\hline GO $12 \mathrm{mU}(9)$ & $49.5 \pm 2.7$ \\
\hline GO $12 \mathrm{mU}+$ catalase $(2,500 \mathrm{U} / \mathrm{ml})(6)$ & $3.1 \pm 1.6$ \\
\hline GO $12 \mathrm{mU}+$ catalase (autoclaved) (4) & $50.9 \pm 4.3$ \\
\hline GO $12 \mathrm{mU}+$ albumin $(70 \mu \mathrm{g} / \mathrm{ml})(2)$ & $50.0 \pm 4.3$ \\
\hline GO (autoclaved) (3) & $-1.1 \pm 0.2$ \\
\hline
\end{tabular}

- Results are expressed as mean ( \pm SE) cytotoxicity of confluent L2 cells monolayers $\left(2.5 \times 10^{5}\right.$ cells). The spontaneous ${ }^{51} \mathrm{Cr}$ release from the L2 cells was $5.2 \pm 0.8 \%$.

t Reagents and L2 cells were incubated in HBSS (pH $7.111 \mathrm{mM}$ glucose) for $4 \mathrm{~h}$ at $37^{\circ} \mathrm{C}$.

$\$ \mathrm{GO}$, glucose oxidase.

"Number of determinations.

min mediates a $29 \%$ L2 cell toxicity (see Table III). This compares to a level of cytotoxicity produced by 16 million stimulated PMN, which produce $4.8 \mathrm{nmol}$ $\mathrm{H}_{2} \mathrm{O}_{2} / \mathrm{min}$. (Fig. 1). The quantitative difference in hydrogen peroxide producing similar cytotoxicity may reflect a contribution of $\mathrm{O}_{\bar{Z}}^{-}$or other cytotoxic factors in the biological PMN system.

\section{DISCUSSION}

Destruction of previously normal lung tissue is seen after inflammation in multiple clinical entities (48-50). One mechanism for this lung cell damage is felt to be the influx of PMN that release a variety of cytotoxic factors. Pulmonary oxygen toxicity is one such clinical situation $(1,2,17,18)$. Our studies indicate that stimulated PMN damage three different cell lines derived from critical lung cell types. Moreover the studies demonstrate clearly that cells exposed to sustained hyperoxia are more susceptible to PMN-mediated cytotoxicity than are time-matched air controls.

Oxygen exposure studies in vivo usually show only modest morphologic alterations in type II pneumocytes, and fibroblast proliferation $(1,2,51)$. Our in vitro data demonstrate a relative resistance of cell lines derived from these two cells to hyperoxia, and to PMNmediated cytotoxicity. The data also suggest that endothelial cells are particularly susceptible to PMN cytotoxicity and to sustained hyperoxia. The PA-EC showed an enhanced ${ }^{51} \mathrm{Cr}$ release over $48 \mathrm{~h}$ of oxygen exposure (in the absence of PMN) whereas this was not the case for L2 cells and lung fibroblasts. Related observations were made by Block and Stalcup (10) who found endothelial cells to be severely altered after 42 
$\mathrm{h}$ of $100 \%$ oxygen exposure in vitro. In vivo studies usually show early extensive damage to alveolar endothelial cells $(12,52,53)$ and a "double attack" of oxygen metabolites has been proposed: increases in reactive oxygen species in the endothelial cells due both to increased oxygen tensions, and to release of oxygen metabolites from adjacent circulating blood cells (11).

It appears that endothelial cells are not only exposed to a double attack but they are uniquely susceptible to both factors. They appear to have an intrinsically poorer defense against PMN-mediated oxidant damage as compared with $\mathrm{L} 2$ cells and LF, and are more sensitive to hyperoxia. The susceptibility of PA-EC to PMN-released oxygen metabolites may be relevant to situations (e.g., shock lung) that are associated with primary injury of lung endothelial cells, and in which PMN may contribute to the microvascular injury (54-56).

The data indicate that PMN-mediated cytotoxicity may be attributed to specific oxygen metabolites. Because no cytolysis was observed in the presence of catalase, the main toxic species appears to be hydrogen peroxide, which independently, or in collaboration with other cytotoxic factors, exerts its effect. The data comparing the amount of $\mathrm{H}_{2} \mathrm{O}_{2}$ generated by glucose oxidase, and the amount of $\mathrm{H}_{2} \mathrm{O}_{2}$ generated by stimulated neutrophils to induce a similar target cell damage are consistent with either explanation. Although stimulated PMN release not only oxygen metabolites but proteolytic enzymes as well (57), no independent effect of these proteins was noted in our system (i.e., catalase was fully protective).

Superoxide dismutase at high concentrations had a small protective effect, but as outlined in Results, a definitive role for $\mathrm{O}_{\dot{2}}^{\bar{z}}$ in the cytotoxic event could not be established. It appears that, if anything, $\mathrm{O}_{\overline{\mathbf{z}}}$ alone is a "minor" toxic metabolite, and it exerts its effect only in the presence of $\mathrm{H}_{2} \mathrm{O}_{2}$. It has been proposed that in the presence of a catalyst, $\mathrm{O}_{2}^{\overline{2}}$ and $\mathrm{H}_{2} \mathrm{O}_{2}$ may interact to form the very powerful oxidant $\mathrm{OH}^{*}(58$, 59 , and cytotoxicity of this oxidant has been shown under some experiment conditions $(24,60)$. In our studies, the addition of three different hydroxyl radical scavengers failed to inhibit neutrophil-mediated cytotoxicity, thus no role for this reactive oxygen species could be demonstrated.

Previous work has similarly implicated $\mathrm{H}_{2} \mathrm{O}_{2}$ as the agent primarily responsible for PMN-mediated cell toxicity. Nathan et al. (21) reported that killing of several target cells by PMA-stimulated mouse macrophages could be reduced by catalase but not by superoxide dismutase. Recently, Weiss et al. (22) showed that human umbilical cord vein endothelial cells could be destroyed by hydrogen peroxide alone using PMA- stimulated neutrophils as the effector cell. Using the same target cells and complement-stimulated neutrophils, Sachs et al. (61) demonstrated only a small and inconsistent SOD effect. Simon et al. (62), using xanthine/xanthine oxidase as a system to generate reactive oxygen metabolites, found $\mathrm{H}_{2} \mathrm{O}_{2}$ to be responsible for toxicity in a human fibroblast cell line. No direct effect was attributable to $\mathrm{O}_{\overline{2}}^{\overline{2}}, \mathrm{OH}^{*}$, or singlet oxygen.

In some studies however, a major role for oxygen metabolites other than $\mathrm{H}_{2} \mathrm{O}_{2}$ is emphasized. For example, SOD does protect erythrocyte target cells against PMN-mediated damage, while catalase or hydroxyl radical scavengers do not $(23,29)$. In other cytolysis studies, a requirement for the myeloperoxidase$\mathrm{H}_{2} \mathrm{O}_{2}$-halide system was found $(40,41)$. The conflicting data suggest that different target cells are specifically susceptible to a different variety of oxidants, with cytotoxicity dependent on cell antioxidant mechanisms, incubation conditions, and the source of oxygen metabolites.

The mechanisms for the enhanced susceptibility of the three lung cell lines to $\mathrm{PMN}$ (i.e., $\mathrm{H}_{2} \mathrm{O}_{2}$ )-mediated cytotoxicity after exposure to sustained hyperoxia is not apparent. Primary lung cell damage produced by hyperoxia is most likely the result of increased quantities of reactive oxygen metabolites $(11-13,16)$. The lung cells could be altered nonspecifically, and the increased susceptibility to PMN cytotoxicity may simply reflect an additive burden by similar oxygen metabolites. Alternatively, because hydrogen peroxide is a small uncharged molecule that would be expected to cross cell membranes easily; the increased susceptibility of oxygen-exposed lung cells may be related to a specific impairment of the hydrogen peroxide detoxifying enzymes glutathione peroxidase and/or catalase. Nathan et al. (63) have shown that $\mathrm{H}_{2} \mathrm{O}_{2}$ toxicity is, in fact, increased by inhibition of the glutathione cycle. Earlier studies assaying lung homogenates of oxygen-exposed animals have shown an increase in lung antioxidant defense systems (64-66), but these studies cannot give information about changes on the cellular level. In subsequent studies we have attempted to define whether the different susceptibility of the three lung cells tested and the increase in susceptibility after sustained hyperoxic exposure is related to the functional status of these antioxidant enzymes. ${ }^{2}$

Several limitations of our study should be kept in mind. Pulmonary artery endothelial cells were used and not endothelial cells of the microvasculature of the lung. Further, the endothelial cells used originate from a calf, whereas the L2 cells and the lung fibroblasts were obtained from rats. Unfortunately, rat lung

\footnotetext{
${ }^{2}$ Suttorp, N., and L. M. Simon, Manuscript submitted for publication.
} 
endothelial cell cultures of capillary origin have not been established (67). It is also possible that the aerobically maintained pulmonary artery endothelial cells were already exposed to relative hyperoxia because these cells are normally exposed to a $\mathrm{PO}_{2}$ of $\sim 40$ torr in vivo. In addition, although the culture-maintained L2 cell line is a clone derived from a rat type II pneumocyte (25), replication and maintenance may result in a variety of physiologic and biochemical alterations. Precise characterization of specialized cell types in tissue culture may be difficult and there is no established identity between the cloned line and type II pneumocytes in situ.

These studies do not address the contribution of alveolar macrophages to lung cell damage after hyperoxic exposure. However, alveolar macrophages are only a minor subpopulation of lung cells, even in the oxygen-poisoned lung (2); further, alveolar macrophages show an impaired respiratory burst after sustained oxygen exposure (68). It is clear that $\mathrm{O}_{2}$-exposed alveolar macrophages release a chemoattractant for PMN and factors to stimulate these neutrophils (18, 69). Thus alveolar macrophages seem to amplify an acute inflammatory response. More studies are necessary to define the role of alveolar macrophages in pulmonary oxygen toxicity.

The applicability of our results (in all three lines) to cell types in situ is therefore not clear. Despite these limitations, and the absence of specific data on mechanisms of enhanced cytotoxicity after oxygen exposure, it is clear that increased susceptibility to PMNmediated oxidant damage is a toxic effect of hyperoxia on lung cells. In addition, this specific manifestation of oxygen injury provides insight into the integration between primary and secondary mechanisms with respect to the cellular basis for pulmonary oxygen toxicity.

\section{ACKNOWLEDGMENTS}

This work was supported by the German Academic Exchange Service (Deutscher Akademischer Austauchdienst), the Francis B. North Foundation, and the Veterans Administration Research Service.

\section{REFERENCES}

1. Kistler, G. S., P-R. B. Caldwell, and E. R. Weibel. 1967 Development of fine structural damage to alveolar and capillary lining cells in oxygen-poisoned rat lungs. $J$. Cell Biol. 33: 605-628.

2. Crapo, J. D., B. E. Barry, H. A. Foscue, and J. Shelburne. 1980. Structural and biochemical changes in rat lungs occurring during exposures to lethal and adaptive doses of oxygen. Am. Rev. Respir. Dis. 122: 123-143.

3. Simon, L. M., T. A. Raffin, W. H. J. Douglas, J. Theodore, and E. D. Robin. 1979. Effects of high oxygen exposure on bioenergetics in isolated type II pneumocytes. $J$.
Appl. Physiol. Respir. Environ. Exercise Physiol. 47: 98103.

4. Raffin, T. A., W. Douglas, L. M. Simon, J. Theodore, and E. D. Robin. 1977. Effects of hyperoxia on ultrastructure and superoxide dismutase (SOD) activity in cultured type II pneumocytes. Clin. Res. 25: 422A.

5. Balin, A. T., D. B. P. Goodman, H. Rasmussen, and V. J. Cristofalo. 1976. The effect of oxygen tension on the growth and metabolism of WI-38 cells. J. Cell Physiol. 89: 235-250.

6. Simon, L. M., S. G. Axline, and E. D. Robin. 1978. The effect of hyperoxia on phagocytosis and pinocytosis in isolated pulmonary macrophages. Lab. Invest. 39: 541546.

7. Simon, L. M., J. Liu, J. Theodore, and E. D. Robin. 1977. Effect of hyperoxia, hypoxia, and maturation on superoxide dismutase activity in isolated alveolar macrophages. Am. Rev. Respir. Dis. 115: 279-284.

8. Raffin, T. A., L. M. Simon, D. Braun, J. Theodore, and E. D. Robin. 1980. Impairment of phagocytosis by moderate hyperoxia (40 to 60 percent oxygen) in lung macrophages. Lab. Invest. 42: 622-626.

9. Rister, M., and R. L. Baehner. 1976. The alteration of superoxide dismutase, catalase, glutathione peroxidase, and $\mathrm{NAD}(\mathrm{P}) \mathrm{H}$ cytochrome $\mathrm{c}$ reductase in guinea pig polymorphonuclear leukocytes and alveolar macrophages during hyperoxia. J. Clin. Invest. 58: 1174-1184.

10. Block, E. R., and S. A. Stalcup. 1981. Depression of serotonin uptake by cultured endothelial cells exposed to high $\mathrm{O}_{2}$ tension. J. Appl. Physiol. Respir. Environ. Exercise Physiol. 50: 1212-1219.

11. Frank, L., and D. Massaro. 1980. Oxygen toxicity. Am. J. Med. 69: 117-126.

12. Deneke, S. M., and B. L. Fanburg. 1980. Normobaric oxygen toxicity of the lung. N. Engl. J. Med. 303: 7686.

13. Fridovich, I. 1976. Oxygen radicals, hydrogen peroxide, and oxygen toxicity. In Free Radicals in Biology, Vol. I. W. A. Pryor, editor. Academic Press, Inc., New York. 239-277.

14. McCord, J. M., and I. Fridovich. 1978. The biology and pathology of oxygen radicals. Ann. Intern. Med. 89: 122-127.

15. Chance, B., and A. Boveris. 1979. Hyperoxia and hydroperoxide metabolism. In Extrapulmonary Manifestations of Respiratory Disease. Lung Biology in Health and Disease, E. D. Robin, editor. Marcel Dekker, Inc. New York. 8: 185-237.

16. Freeman, B. A., and J. D. Crapo. 1981. Hyperoxia increases oxygen radical production in rat lungs and lung mitochondria. J. Biol. Chem. 256: 10986-10992.

17. Nickerson, P. A., S. Matalon, and L. E. Farhi. 1981. An ultrastructural study of alveolar permeability to cytochrome $\mathrm{C}$ in the rabbit lung. Effect of exposure to $100 \%$ oxygen at one atmosphere. Am. J. Pathol. 102: 1-9.

18. Fox, R. B., J. R. Hoidal, D. M. Brown, and J. E. Repine. 1981. Pulmonary inflammation due to oxygen toxicity: involvement of chemotactic factors and polymorphonuclear leukocytes. Am. Rev. Respir. Dis. 123: 521-523.

19. Shasby, D. M., R. B. Fox, R. N. Harada, and J. E. Repine 1980. Mechanisms of pulmonary oxygen toxicity: neutropenia protects against acute lung injury from hyperoxia. Am. Rev. Respir. Dis. 121(4, Pt. 2): 258. (Abstr.).

20. Klebanoff, S. J. 1980. Oxygen metabolism and the toxic properties of phagocytes. Ann. Intern. Med. 93: 480489. 
21. Nathan, C. F., S. C. Silverstein, L. H. Brukner, and Z. A. Cohn. 1979. Extracellular cytolysis by activated macrophages and granulocytes. II. Hydrogen peroxide as a mediator of cytotoxicity. J. Exp. Med. 149: 100113.

22. Weiss, S. J., J. Young, A. F. LoBuglio, A. Slivka, and N. F. Nimeh. 1981. Role of hydrogen peroxide in neutrophil-mediated destruction of cultured endothelial cells. J. Clin. Invest. 68: 714-721.

23. Weiss, S. J. 1980. The role of superoxide in the destruction of erythrocyte targets by human neutrophils. J. Biol. Chem. 255: 9912-9917.

24. Johnston, R. B. Jr., B. B. Keele, Jr., H. P. Misra, J. E. Lehmeyer, L. S. Webb, R. L. Baehner, and K. V. Rajagopalan. 1975. The role of superoxide anion generation in phagocytic bactericidal activity. Studies with normal and chronic granulomatous disease leukocytes. J. Clin. Invest. 55: 1357-1372.

25. Douglas, W. H. J., and M. E. Kaighn. 1974. Clonal isolation of differentiated rat lung cells. In Vitro (Rockville). 10: 230-237.

26. Simon, L. M., E. D. Robin, and J. Theodore. 1981. Differences in oxygen dependent regulation of enzymes between tumor and normal cell systems in culture. $J$. Cell Physiol. 108: 393-400.

27. Simon, L. M., E. D. Robin, T. A. Raffin, J. Theodore, and W. H. J. Douglas. 1978. Bioenergetic pattern of isolated type II pneumocytes in air and during hypoxia. J. Clin. Invest. 61: 1232-1239.

28. Ryan, U. S., E. Clements, D. Habilston, and J. W. Ryan. 1978. Isolation and culture of pulmonary artery endothelial cells. Tissue \& Cell. 10: 535-554.

29. Oren, R., A. E. Farnham, K. Saito, E. Milofsky, and M. L. Karnovsky. 1963. Metabolic patterns in three types of phagocytozing cells. J. Cell Biol. 17: 487-501.

30. Babior, B. M., R. S. Kipnes, and J. T. Curnutte. 1973. Biological defense mechanisms. The production by leukocytes of superoxide, a potential bactericidal agent. $J$. Clin. Invest. 52: 741-744.

31. Chance, B., and G. R. Williams. 1956. The respiratory chain and oxidative phosphorylation. Adv. Enzymol. Relat. Areas Mol. Biol. 17: 65-134.

32. Root, R. K., J. Metcalf, N. Oshino, and B. Chance. 1975. $\mathrm{H}_{2} \mathrm{O}_{2}$ release from human granulocytes during phagocytosis. I. Documentation, quantitation, and some regulating factors. J. Clin. Invest. 55: 945-955.

33. Root, R. K., and J. A. Metcalf. 1977. $\mathrm{H}_{2} \mathrm{O}_{2}$ release from human granulocytes during phagocytosis. Relationship to superoxide anion formation and cellular catabolism of $\mathrm{H}_{2} \mathrm{O}_{2}$ : studies with normal and cytochalasin B-treated cells. J. Clin. Invest. 60: 1266-1279.

34. Colton, T. 1974. Statistics in Medicine. Little, Brown and Co., Inc., Boston.

35. DeChatelet, L. R., P. S. Shirley, and R. B. Johnston, Jr. 1976. Effect of phorbol myristate acetate on the oxidative metabolism of human polymorphonuclear leukocytes. Blood. 47: 545-554.

36. Repine, J. E., J. G. White, C. C. Clawson, and B. M. Holmes. 1974. Effects of phorbol myristate acetate on the metabolism and ultrastructure of neutrophils in chronic granulomatous disease. J. Clin. Invest. 54: 83-90.

37. Badway, J. A., J. T. Curnutte, J. M. Robinson, J. K. Lazdins, R. T. Briggs, M. J. Karnovsky, and M. L. Karnovsky. 1980. Comparative aspects of oxidative metabolism of neutrophils from human blood and guinea pig peritonea: magnitude of the respiratory burst, dependence upon stimulating agents, and localization of the oxidase. $J$. Cell. Physiol. 105: 541-551.

38. Goldstein, I. M., D. Roos, H. B. Kaplan, and G. Weissmann. 1975. Complement and immunoglobulin stimulate superoxide production by human leukocytes independently of phagocytosis. J. Clin. Invest. 56: 11551163.

39. Simchowitz, L., and I. Spilberg. 1979. Evidence for the role of superoxide radicals in neutrophil-mediated cytotoxicity. Immunology. 37: 301-309.

40. Clark, R. A., and S. J. Klebanoff. 1975. Neutrophil-mediated cell cytotoxicity: Role of the peroxidase system. J. Exp. Med. 141: 1442-1447.

41. Clark, R. A., and S. Szot. 1981. The myeloperoxidasehydrogen peroxide-halide system as effector of neutrophil-mediated tumor cell cytotoxicity. J. Immunol. 126: 1295-1301.

42. Hodgson, E. K., and I. Fridovich. 1975. The interaction of bovine erythrocyte superoxide dismutase with hydrogen peroxide: chemiluminescence and peroxidation. Biochemistry. 14: 5299-5303.

43. Spikes, J. D., and H. M. Swartz. 1978. International conference on singlet oxygen and related species in chemistry and biology, review and general discussion. Photochem. Photobiol. 28: 921-933.

44. Rosen, H., and S. J. Klebanoff. 1979. Hydroxyl radical generation by polymorphonuclear leukocytes measured by electron spin resonance spectroscopy. J. Clin. Invest. 64: 1725-1729.

45. Weiss, S. J., P. K. Rustagi, and A. F. LoBuglio. 1978. Human granulocyte generation of hydroxyl radical. $J$. Exp. Med. 147: 316-323.

46. Repine, J. E., J. W. Eaton, M. W. Anders, J. R. Hoidal, and R. B. Fox. 1979. Generation of hydroxyl radical by enzymes, chemicals, and human phagocytes in vitro. $J$. Clin. Invest. 64: 1642-1651.

47. Nilsson, R., F. M. Pick, and R. C. Bray. 1969. EPR studies on reduction of oxygen by some biochemical systems. Biochim. Biophys. Acta. 192: 145-148.

48. McCormick, J. R., M. M. Harkin, K. J. Johnson, and P. A. Ward. 1981. Suppression by superoxide dismutase of immune-complex-induced pulmonary alveolitis and dermal inflammation. Am. J. Pathol. 102: 55-61.

49. Johnson, K. J., and P. A. Ward. 1981. Role of oxygen metabolites in immune complex injury of lung. J. Immunol. 126: 2365-2369.

50. Turino, G. M., J. R. Rodriguez, L. M. Greenbaum, and I. Mandl. 1974. Mechanisms of pulmonary injury. Am. J. Med. 57: 493-505.

51. Crapo, J. D., M. Peters-Golden, J. Marsh-Salin, and J. S. Shelburne. 1978. Pathologic changes in the lungs of oxygen-adapted rats. A morphometric analysis. $L a b$. Invest. 39: 640-653.

52. Weibel, E. R. 1971. Oxygen effect on lung cells. Arch. Intern. Med. 128: 54-56.

53. Bowden, D. H., and I. Y. R. Adamson. 1974. Endothelial regeneration as a marker of the differential vascular responses in oxygen-induced pulmonary edema. Lab. Invest. 30: 350-357.

54. Robin, E. D. 1980. Basic aspects of pulmonary dysfunction as related to hemotherapy. Bibl. Haematol. 46: 210219.

55. Heflin, A. C., and K. L. Brigham. 1981. Prevention by granulocyte depletion of increased vascular permeability of sheep lung following endotoxemia. J. Clin. Invest. 68: 1253-1260. 
56. Tate, R. M., K. M. Van Benthuysen, D. M. Shasby, I. F. McMurtry, C. M. Bowman, R. N. Harada, R. B. Fox, and J. E. Repine. 1981. Dimethylthiourea, a hydroxyl radical scavenger, blocks oxygen radical induced acute edematous lung injury in an isolated perfused lung. Am. Rev. Respir. Dis. 123(4, Pt. 2): 243. (Abstr.).

57. Henson, P. M., and Z. G. Oades. 1975. Stimulation of human neutrophils by soluble and insoluble immunoglobulin aggregates. Secretion of granule constituents and increased oxidation of glucose. J. Clin. Invest. 56: 1053-1061.

58. Cohen, G. 1977. In defense of Haber-Weiss. In Superoxide and Superoxide dismutase. A. M. Michelson, J. M. McCord, and I. Fridovich, editors. Academic Press, Inc., New York. 317-321.

59. Willson, R. L. 1979. Hydroxyl radicals and biological damage in vitro: what relevance in vivo? In Oxygen Free Radicals and Tissue Damage. Ciba Foundation Symposium 65. Excerpta Med. Amsterdam. 19-35.

60. Repine, J. E., R. B. Fox, and E. M. Berger. 1981. Hydrogen peroxide kills staphylococcus aureus by reacting with staphylococcal iron to form hydroxyl radical. $J$. Biol. Chem. 256: 7094-7096.

61. Sacks, T., C. F. Moldow, P. R. Craddock, T. K. Bowers, and H. S. Jacob. 1978. Oxygen radicals mediate endothelial cell damage by complement-stimulated granulocytes. An in vitro model of immune vascular damage. J. Clin. Invest. 61: 1161-1167.

62. Simon, R. H., C. H. Scoggin, and D. Patterson. 1981. Hydrogen peroxide causes the fatal injury to human fi- broblasts exposed to oxygen radicals. J. Biol. Chem. 256: 7181-7186.

63. Nathan, C. F., B. A. Arrick, H. W. Murray, N. M. DeSantis, and Z. A. Cohn. 1981. Tumor cell anti-oxidant defenses. Inhibition of the glutathione redox cycle enhances macrophage-mediated cytolysis. J. Exp. Med. 153: 766-782.

64. Crapo, J. D., and D. F. Tierney. 1974. Superoxide dismutase and pulmonary oxygen toxicity. Am. J. Physiol. 226: 1401-1407.

65. Kimball, R. E., K. Reddy, T. H. Peirce, L. W. Schwartz, M. G. Mustafa, and C. E. Cross. 1976. Oxygen toxicity: augmentation of antioxidant defense mechanisms in rat lung. Am. J. Physiol. 230: 1425-1431.

66. Frank, L., J. R. Bucher, and R. J. Roberts. 1978. Oxygen toxicity in neonatal and adult animals of various species. J. Appl. Physiol. Respir. Environ. Exercise Physiol. 45: 699-704.

67. Habliston, D. L., C. Whitaker, M. A. Hart, U. S. Ryan, and J. W. Ryan. 1979. Isolation and culture of endothelial cells from the lungs of small animals. Am. Rev. Respir. Dis. 119: 853-868.

68. Suttorp, N., and L. M. Simon. 1981. Impairment of bactericidal mechanisms in lung macrophages exposed to sustained hyperoxia. Clin. Res. 29: 71A.

69. Fox, R. B., J. R. Hoidal, D. M. Brown, and J. E. Repine. 1980. Mechanism of pulmonary oxygen toxicity: hyperoxia damaged alveolar macrophages release factors which attract polymorphonuclear leukocytes and stimulate their release of superoxide $\left(\mathrm{O}_{\dot{2}}^{\bar{z}}\right)$. Clin. Res. 28: 528A. 